\title{
Strategic Fragmented Markets
}

\author{
Ana Babus * $\quad$ Cecilia Parlatore ${ }^{\ddagger}$
}

February 15, 2016

\begin{abstract}
We propose a theory to understand when there is fragmentation in asset markets. To do so we develop a model of market formation in which investors with heterogeneous valuations trade an asset strategically. Investors choose a dealer with whom to trade. After the market structure is decided, trade takes place sequentially. First, each dealer and his investors trade strategically in a local market. Second, dealers participate in a strategic inter-dealer market. Markets are fragmented when there are multiple active dealers. In contrast, the market is centralized if all investors choose to trade with the same dealer. In equilibrium, market fragmentation depends on the dispersion of the investors' valuations for the asset and on the dealers' opportunities to intermediate through the inter-dealer market. Increasing the number of market participants in the local market always decreases the investors' price impact and, thus, their cost of trading. At the same time, it also decreases the investors' gains from trade when their valuations are less dispersed. This second effect dominates when the dealers' willingness to intermediate is low. We show that investors choose to trade in fragmented markets when their valuations are highly correlated and when intermediation is limited. We compare investors' and dealers' welfare in fragmented and centralized markets. The model also has implication for liquidity and price dispersion.
\end{abstract}

*Federal Reserve Bank of Chicago; anababus@gmail.com

${ }^{\dagger}$ NYU Stern; cparlato@stern.nyu.edu.

¥The views expressed in this paper do not represent the Federal Reserve Bank of Chicago or the Federal Reserve System. 